International Journal of Social Science (IJSS)

Vol.1 Issue.5 February 2022, pp: 799-808

ISSN: 2798-3463 (Printed) | 2798-4079 (Online)

\title{
THE EFFECT OF WORK EXPERIENCE, INTEGRITY, AND COMPETENCE OF AUDITORS ON AUDIT QUALITY WITH EMOTIONAL INTELLIGENCE AS A MODERATING VARIABLE (Case Study on BPKP South Sulawesi Province)
}

\author{
By \\ Andi Hardianti ${ }^{1}$, Alimuddin ${ }^{2}$, Syamsuddin $^{3}$ \\ ${ }^{1}$ Master of Accounting Student, Hasanuddin University, Makassar \\ ${ }^{2,3}$ Lecturer, Accounting Study Program, Hasanuddin University, Makassar \\ Email: ${ }^{1}$ ahardianti2@gmail.com
}

\begin{tabular}{l}
\hline \hline Article Info \\
\hline Articlehistory: \\
Received Nov 17, 2021 \\
Revised Dec 21, 2021 \\
Accepted Jan 27, 2022 \\
\\
\hline Keywords: \\
Auditor Work Experience, \\
Auditor Integrity, \\
Auditor Competence, \\
Audit quality, \\
Emotional intelligence
\end{tabular}

CorrespondingAuthor:

Andi Hardianti

Master of Accounting Student, Hasanuddin University, Makassar

Email: ahardianti2@gmail.com

\begin{abstract}
This study aims to analyze the effect of auditor's work experience, integrity and competence of auditors on audit quality at the Office of the Financial and Development Supervisory Agency Representative for South Sulawesi Province. With emotional intelligence as a moderating variable. This study uses moderated regression analysis (MRA) using the SPSS Version 28 application. The results of the analysis show that the variables that have a direct effect on audit quality and fulfill significant assumptions are: Auditor work experience and auditor integrity. while auditor competence has no significant effect on audit quality. Auditor work experience with a $p$ value of $0.032>0.05$, meaning that the higher the auditor's work experience $(X 1)$, the better the audit quality $(Y)$ produced. Auditor integrity with $p$ value $0.001<0.05$, it means that the higher the auditor integrity $(X 2)$, the higher the audit quality $(Y)$. auditor competence with $p$ value $0.746<0.05$, meaning that auditor competence (X3) has no significant effect on audit quality ( $Y$ ). The results of the moderating regression analysis for the effect of emotional intelligence (Z) in moderating the relationship between auditor's work experience $(X 1)$ on audit quality $(Y)$ showed a probability value of $0.016<0.050$. The value indicates that emotional intelligence has a positive and significant effect in moderating the relationship between auditor work experience and audit quality. The results of the regression analysis for the effect of emotional intelligence $(Z)$ in moderating the relationship between auditor integrity $(X 2)$ and audit quality $(Y)$ show a probability value of $0.010<0.050$. This value indicates that emotional intelligence has a positive and significant effect in moderating the relationship between auditor integrity and audit quality. The results of the regression analysis for the effect of emotional intelligence $(Z)$ in moderating the relationship between auditor competence (X3) on audit quality showed a probability value of $0.010<0.050$. The value indicates that emotional intelligence has a significant effect in moderating the relationship between auditor competence and audit quality.
\end{abstract}

Thisisan open accessarticleundertheCC BY-SAlicense.

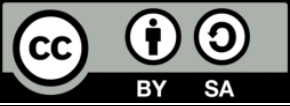

\section{INTRODUCTION}

Based on Presidential Regulation Number 192 of 2014, BPKP has the task of carrying out government affairs in the field of state/regional financial supervision and national development. In carrying out these tasks, BPKP carries out two main functions, namely first, the function of directing and coordinating internal supervision. Second, the internal control function. The implementation of these two functions emphasizes effectiveness and efficiency as the basis for achieving goals through an internal process of risk-based monitoring activities, 
establishing an effective partnership pattern with stakeholders, and fulfilling compliance with policies and regulations.

Based on the 2020 performance report at the BPKP Representative for South Sulawesi Province. There are 30 indicators of the program being implemented, 24 indicators of the program "very successful", 5 indicators of the program "not reaching the target" and 1 program "not being able to be implemented". As in table 1.1 below:

Tabel 1.1

Unsuccessful Program Indicators

\begin{tabular}{|c|c|c|c|c|}
\hline NO & Indicator Program & Target & Realization & Category \\
\hline 1 & $\begin{array}{c}\text { Value of realized state/regional } \\
\text { revenue optimization }\end{array}$ & $100 \%$ & $48,52 \%$ & have not reached the target \\
\hline 2 & $\begin{array}{c}\text { The value of saving state and regional } \\
\text { finances }\end{array}$ & $100 \%$ & $48,79 \%$ & have not reached the target \\
\hline 3 & $\begin{array}{c}\text { Number of District/City Local } \\
\text { Governments with MRI 0\% Level 3 }\end{array}$ & $100 \%$ & $0 \%$ & have not reached the target \\
\hline 4 & $\begin{array}{c}\text { Percentage of Employees who take part } \\
\text { in 86\% increase in Competence }\end{array}$ & $100 \%$ & $86 \%$ & have not reached the target \\
\hline 5 & Work Unit SPIP Maturity & $100 \%$ & $0 \%$ & have not reached the target \\
\hline
\end{tabular}

The 2020 Performance Report at the BPKP Representative of South Sulawesi Province explained that the realized state/regional revenue optimization value was Rp. 76,597,539.00 from the target of Rp. 158,000,000.00 so that the achievement was $48.52 \%$ and the value of saving state and regional finances was Rp. $13.233,918,445.40$ of the target of Rp.27,124,000,000, so the achievement was $48.79 \%$. This indicates that internal control is still weak in the government order and it indicates that it will not close the gap that fraud is still occurring in financial reporting.

Phenomena related to financial reporting errors occurred at PT. Garuda Indonesia (Persero) Tbk announced by the Financial Services Authority (OJK) as of December 31, 2018. In the financial report, Garuda Indonesia Group posted a net profit of USD 809.85 thousand or equivalent to Rp 11.33 billion (assuming an exchange rate of Rp. 14,000 per US dollar). This figure jumped sharply compared to 2017 which suffered a loss of USD 216.5 million. Where the funds should be receivables but recognized as income by PT. Garuda Indonesia (Persero) Tbk. (kemenkeu.go.id)

Coupled with the opinion of the Unqualified audit opinion issued by KAP TanubrataSutantoFahmi Bambang \&Rekan (Member of BDO International) on the financial statements. Garuda Indonesia VP Corporate Secretary, M Ikhsan Rosan in Fajar Indonesia Network (FIN). The impact of these problems is certainly very detrimental to various parties, including users of financial statements due to the low audit quality. The decrease in the level of trust of various parties to the auditor regarding the quality of the audit of financial statements has resulted in the imposition of sanctions both on the auditor as an inspection and for PT Garuda Indonesia (Persero) itself.One of the functions of the auditor is to find errors or discrepancies in recording with applicable standards. This is very crucial in reporting the accountability of the company's management performance to interested parties as a result of consideration of the auditor's report (Thesy Bonita Sitorus, 2015). Similar to the role of BPKP as an internal auditor institution that was formed to create good and clean governance, it should be able to carry out its roles and functions for the sake of good governance as regulated in Articles 2 and 3 of the Presidential Regulation of the Republic of Indonesia Number 192 of 2014 concerning Agency Financial and Development Supervision (BPKP).

These thoughts and problems, the researcher assumes that the importance of the quality of the audit produced by the auditor can provide confidence to interested parties on the truth of the audited financial statements. There are several factors that can affect audit quality including work experience, integrity and competence of auditors. In accordance with PERMENPAN No: PER/05/M.PAN/03/2008 concerning Audit of Government Internal Supervisory Apparatus (APIP) states that in general standards of performance audit and investigative audit may include applicable standards with characteristics of organizations and individuals who conducting audit activities must have sufficient experience, have high integrity, be objective, have competence (skills, education, and ongoing training), professional accuracy and compliance with the code of ethics.Auditors who have high experience will differ in viewing and responding to information obtained during the examination and also in providing audit conclusions on the object being examined in the form of giving an opinion. The more experience an auditor has, the more appropriate the consideration of the level of materiality in the company's financial statements will be. In addition, the better the views and responses about the information contained in the financial statements, because the auditors have done a lot of their duties or have examined the financial statements of various types of industries (Novanda, 2012: 28). This is in line with the research of Queena and Rohman (2012), as well as research conducted 
International Journal of Social Science (IJSS)

Vol.1 Issue.5 February 2022, pp: 799-808

ISSN: 2798-3463 (Printed) | 2798-4079 (Online)

DOI: https://doi.org/10.53625/ijss.v1i5.1325

by Lehman and Norman (2006) in Mabruri and Winarna (2010), regarding the effect of experience on the complexity of problems and audit judgment, found that experienced auditors (expertise), will more clearly detail the problems faced compared to inexperienced auditors, which will later affect auditor judgment.

Auditor integrity is also an important factor in supporting audit activities carried out by an auditor. Integrity is a principle that is embedded in the conscience to always be honest, transparent, courageous, and wise in carrying out audit tasks. The attitude of integrity of an auditor can improve the quality of the resulting audit. The higher the attitude of the auditor's integrity, the higher the quality of the audit produced. Even so, the lower the integrity auditor, the lower the quality of the resulting audit. This is in line with the research conducted by Mabruri and Winarna (2010: 18) that the auditor's integrity, either partially or simultaneously, has a positive effect on the quality of audit results. The same results were also obtained by Queena and Rohman (2012), Fitriani and Yoga (2013), and Pradana (2015). Different research results revealed by Sukriah, Akram, and Biana (2009: 12) that auditor integrity has no significant effect on the quality of audit results. Likewise, research by Harahap (2017: 7) concludes that integrity has no effect on the quality of audit results.

In addition, the competence of auditors also greatly affects audit quality. Sukriah (2009: 6) emphasizes that competence is related to the professional expertise of auditors as a result of formal education, professional examinations and participation in training. This is in line with Government Regulation No. 60 of 2008 article 51 which states that the audit is carried out by officials who meet the competency requirements, which are carried out through participation and graduation of the certification program. While Rai (2011: 63) specifically reveals the competencies that an auditor must have in carrying out a performance audit including personal qualities, general knowledge, and special skills. This is evidenced by research conducted by Effendi (2010) and Badjuri (2012) which concludes that competence has a positive effect on audit quality. Competent people are people with the skills to do work easily, quickly, intuitively and very rarely or never make mistakes. Auditors must undertake sufficient technical training to acquire these skills. Achievement begins with formal education, which is further expanded through audit experience and practice.

Another factor that contributes to producing quality audits is emotional intelligence. According to Wijayanti (2012) emotional intelligence is a capability in managing our responses and emotions when dealing with other people, situations, interaction problems, and stressful conditions, so as to get effective results.

\subsection{Problem Formulation}

Based on the background, this research tries to answer the following questions.

1. Does Auditor's Work Experience Affect Audit Quality at the BPKP Representative Office of South Sulawesi Province?

2. Does Auditor Integrity affect Audit Quality at the BPKP Representative Office of South Sulawesi Province?

3. Does Auditor Competence affect Audit Quality at the BPKP Representative Office of South Sulawesi Province?

4. Can Emotional Intelligence Moderate the Effect of Auditor's Work Experience on Audit Quality at the BPKP Representative Office of South Sulawesi Province?

5. Can Emotional Intelligence Moderate the Effect of Auditor Integrity on Audit Quality at the BPKP Representative Office of South Sulawesi Province?

6. Can Emotional Intelligence Moderate the Effect of Auditor Competency on Audit Quality at the BPKP Representative Office of South Sulawesi Province?

\subsection{Research Objectives}

Based on descriptions of various reference sources and research that has been carried out by previous researchers, the purpose of this study is to test and analyze:

1. To find out the Effect of Work Experience on the Audit Quality of BPKP Representatives of South Sulawesi Province.

2. To find out the Effect of Auditor Integrity on the Audit Quality of BPKP Representatives of South Sulawesi Province.

3. To determine the effect of Auditor Competency on the Audit Quality of BPKP Representatives of South Sulawesi Province.

4. To find out Emotional Intelligence in moderating the Effect of Auditor's Work Experience on the Audit Quality of BPKP Representatives of South Sulawesi Province.

5. To find out Emotional Intelligence in moderating the Effect of Auditor Integrity on the Audit Quality of BPKP Representatives of South Sulawesi Province.

6. To find out Emotional Intelligence in moderating the Effect of Auditor Competency on the Audit Quality of BPKP Representatives of South Sulawesi Province. 


\section{RESEARCH METHOD}

This research is a quantitative research. The population in this study are auditors at the Office of the Financial and Development Supervisory Agency (BPKP) Representative of South Sulawesi Province. In this study, not the entire population was taken, given the large number and not necessarily known with certainty. Therefore, in this study used a sample that is part of the number of characteristics possessed by the population.

The sample was selected from the auditors who work in the South Sulawesi Financial and Development Supervisory Agency office, totaling 147 people, represented by 40 auditors as respondents in the office. The sampling technique used accidental technique (Nonprobability sampling) which was selected based on the researcher's considerations. According to Santoso and Tjiptono (2001:89) accidental sampling (convenience sampling)is a sampling procedure that selects a sample of people or units that are most easily found or accessed. The type of data used by the researcher is primary data (primary data) in the form of a questionnaire that is distributed directly to respondents according to the characteristics of the population using a Likert scale. This study uses a questionnaire as an instrument to obtain data from respondents. The measurement of each research instrument uses an ordinal scale (likert). The data that has been collected will be tested by testing the validity and reliability to ensure the quality of the data before being processed further using SPSS Version 28 application software. Before analyzing the regression model that will be used in this study, first test the classical assumptions so that the conclusions obtained are does not create a biased value. The classical assumption test in this study includes multicollinearity test, heteroscedasticity test, and normality test. The research variables consist of; auditor's work experience, auditor integrity and auditor competence which are independent variables. The dependent variable is audit quality, and the moderating variable is emotional intelligence.

Hypothesis testing in this study uses the analysis of the coefficient of determination (R2) and partial testing ( $t$ test) both before the interaction and after the interaction. The coefficient of determination aims to determine the best level of accuracy in regression analysis, which is indicated by the magnitude of the coefficient of determination (R2) between 0 (zero) and 1 (one). The coefficient of determination (R2) 0 indicates that the independent variable has absolutely no effect on the dependent variable, if the coefficient of determination is close to one, it can be concluded that the independent variable has an influence on the dependent variable. The t test is done by comparing the $\mathrm{t}$ count with the $\mathrm{t}$ table. To determine the value of $\mathrm{t}$ table is determined with a significance value of $5 \%$ with degrees of freedom $\mathrm{df}=(\mathrm{n}-\mathrm{k}-1)$ where $\mathrm{n}$ is the number of respondents and $\mathrm{k}$ is the number of variables. $\mathrm{T}$ test is done by comparing $\mathrm{t}$ count with $\mathrm{t}$ table. To determine the value of $\mathrm{t}$ table is determined with a significance value of $5 \%$ with degrees of freedom $\mathrm{df}=(\mathrm{n}-\mathrm{k}-1)$ where $\mathrm{n}$ is the number of respondents and $\mathrm{k}$ is the number of variables. (Sugiyono, 2013). The criteria for accepting and rejecting the hypothesis are:

1. If $\mathrm{t}$ table $<\mathrm{t}$ count then Ho is accepted

2. If $t$ count $<t$ table then Ho is rejected.

In addition, the t-test can also be seen from the magnitude of the probability value ( $\mathrm{P}$ Value) which is compared to 0.5 (significance level $=0.5 \%$ ). The test criteria used are:

1. If $\mathrm{P}$ Value $>0.05$ then Ho is accepted.

2. If $\mathrm{P}$ Value $<0.05$ then Ho is rejected.

\section{RESULTS AND DISCUSSION}

The value of the determinant coefficient $\mathrm{R}$ Isquare in the test results summary table 3.1 shows a value of 0.736 or $73.60 \%$. These results indicate that the audit quality variable is influenced by the auditor's work experience (X1), auditor integrity (X2), and auditor competence (X3) of $73.60 \%$. The remaining $26.40 \%$ is influenced by other variables outside of the independent variables studied in this study a dependen variabel: $\mathrm{Y}$

Tabel 3.1 Results of Multiple Regression Analysis

\begin{tabular}{|c|c|c|c|c|c|c|c|}
\hline \multirow[t]{2}{*}{ Mode } & \multicolumn{2}{|c|}{$\begin{array}{l}\text { Unstandardized } \\
\text { Coefficients }\end{array}$} & \multirow{2}{*}{$\begin{array}{l}\text { Standardized } \\
\text { Coefficients } \\
\text { Beta }\end{array}$} & \multirow[t]{2}{*}{$\mathrm{t}$} & \multirow[t]{2}{*}{ Sig. } & \multicolumn{2}{|c|}{ Collinearity Statistics } \\
\hline & B & $\begin{array}{l}\text { Std. } \\
\text { Error }\end{array}$ & & & & Tolerance & VIF \\
\hline (Constant) & -1.453 & 6.964 & & -.209 & .836 & & \\
\hline $\mathrm{X} 1$ & .563 & .252 & 290 & 2.233 & .032 & .447 & 2.235 \\
\hline $\mathrm{X} 2$ & .463 & .124 & .558 & 3.739 & $<.001$ & .339 & 2.949 \\
\hline $\mathrm{X} 3$ & .074 & .226 & .052 & .326 & .746 & .294 & 3.398 \\
\hline $\mathrm{Z}$ & .165 & .121 & .128 & 1.372 & .179 & .869 & 1.150 \\
\hline
\end{tabular}


International Journal of Social Science (IJSS)

Vol.1 Issue.5 February 2022, pp: 799-808

ISSN: 2798-3463 (Printed) | 2798-4079 (Online)

DOI: https://doi.org/10.53625/ijss.v1i5.1325

\begin{tabular}{|c|c|c|c|c|}
\hline \multicolumn{5}{|c|}{ Model Summary } \\
\hline Model & $\mathrm{R}$ & R Square & $\begin{array}{c}\text { Adjusted R } \\
\text { Square }\end{array}$ & $\begin{array}{c}\text { Std. Error of the } \\
\text { Estimate }\end{array}$ \\
\hline 1 & $.858^{\mathrm{a}}$ & .736 & .705 & 2.90160 \\
\hline
\end{tabular}

\begin{tabular}{|c|c|c|c|c|c|c|}
\hline \multicolumn{9}{|c|}{ ANOVA $^{\text {a }}$} \\
\hline Model & & Sum of Squares & df & Mean Square & F & Sig. \\
\hline \multirow{3}{*}{1} & Regression & 819.725 & 4 & 204.931 & 24.341 & $<.001^{\text {b }}$ \\
\cline { 2 - 7 } & Residual & 294.675 & 35 & 8.419 & & \\
\cline { 2 - 7 } & Total & 1114.400 & 39 & & & \\
\hline
\end{tabular}

Based on the results of the regression test above, a mathematical equation can be arranged as follows. $\mathrm{Y}=-1453+0.563 \mathrm{X} 1+0.463 \mathrm{X} 2+0.074 \mathrm{X} 3$

Hypothesis testing in this study was carried out partially by using the $t$ test which can be seen as follows.

1. The effect of auditor's work experience (X1) on audit quality (Y). The auditor's work experience variable (X1) obtained a probability value of 0.032 . Because the probability value is less than $5 \%(0.032<0.050)$, partially the auditor's work experience (X1) has a significant effect on the audit quality variable (Y). Based on the coefficient value of 0.563 is positive, identifying a positive influence. That is, the higher the auditor's (X1). The better the quality of the audit produced. Vice versa, the lower the works experience of the auditor, the lower the audit quality.

2. The effect of auditor integrity (X2) on audit quality (Y). In the auditor integrity variable (X2), the probability value is 0.001 . Because the probability value is smaller than $5 \%(0.001<0.050)$, partially the auditor integrity variable (X2) has a significant effect on the audit quality variable (Y). Based on the coefficient value of 0.463 is positive, identifying a positive effect. This means that the higher the integrity of the auditor (X2), the lower auditor's integrity (X2), the lower quality of the resulting audit (Y).

3. The effect of auditor competence (X3) on audit quality (Y). In the auditor competence variable (X3), the probability value is 0.746 . Because the probability value is 0.746 . Because the probability value is greater than $5 \%(0.746>0.050)$, partially the auditor's competence variable (X3) has no significant effect on the audit quality variable (Y). it can be said that the high competence possessed by the auditor does not guarantee an increase in the quality of the resulting audit. It can be seen that most of the auditors at the BPKP Representative of South Sulawesi Province are at S1 level and there are auditors who have educational backgrounds that are not related to auditing activities. However, the Makassar city government managed to achieve an unqualified opinion (WTP) on the financial statements of the 2020 Regional Revenue and Expenditure Budget (APBD).

Table 3.2 Moderation Regression Analysis Results1 (X1.Z1)

\begin{tabular}{|c|c|c|c|c|c|c|}
\hline \multicolumn{2}{|c|}{ Model } & \multicolumn{2}{c|}{ Unstandardized Coefficients } & Standardized Coefficients & & \multirow{2}{*}{ Sig. } \\
\cline { 3 - 7 } & B & Std. Error & Beta & t & 1.212 & .233 \\
\hline \multirow{3}{*}{1} & Constant) & 8.375 & 6.913 & & 5.603 & $<.001$ \\
\cline { 2 - 7 } & X1 & 1.213 & .217 & .626 & 2.527 & .016 \\
\cline { 2 - 7 } & moderasi1 & .315 & .125 & .282 & 0
\end{tabular}

Based on the results of the moderating regression test, the auditor's work experience variable (X1) on audit quality after interacting with the emotional intelligence variable $(Z)$, the mathematical equation can be arranged as follows.

$$
\mathrm{Y}=8.375+0.315 \mathrm{X} 11 . \mathrm{Z} 1
$$

From table 3.2 Results of Moderation Regression Analysis1 (X1.Z1) it is known that the auditor's work experience variable interacting with emotional intelligence (moderation) has a value of 0.016 below the standard value of 0.05 significance. This shows that emotional intelligence moderates the effect of the auditor's work experience on audit quality. The coefficient for the interaction of the auditor's work experience variable and emotional intelligence of 0.315 is positive, which means that the emotional intelligence variable strengthens the effect of the auditor's work experience on audit quality (Y).

Table 3.3 Moderation Regression Analysis Results2 (X2.Z2)

\begin{tabular}{l|l|l|l|l} 
Model & Unstandardized Coefficients & Standardized Coefficients & t & Sig.
\end{tabular}




\begin{tabular}{|c|c|c|c|c|c|c|}
\hline & & B & Std. Error & Beta & & \\
\hline \multirow[t]{3}{*}{1} & (Constant) & 15.654 & 4.420 & & 3.542 & .001 \\
\hline & $\mathrm{X} 2$ & .576 & .081 & .694 & 7.118 & $<.001$ \\
\hline & Moderasi2 & .308 & .113 & .267 & 2.735 & .010 \\
\hline
\end{tabular}

Based on the results of the moderating regression test of the auditor's integrity variable (X2) on audit quality after interacting with the emotional intelligence variable $(\mathrm{Z})$, the mathematical equation can be arranged as follows.

$$
\mathrm{Y}=15,654+0.308 \mathrm{X} 22 . \mathrm{Z} 2
$$

From the table above, it is known that the auditor's integrity variable interacting with emotional intelligence (moderation) has a value of 0.01 below the standard value of 0.05 significance. This shows that emotional intelligence moderates the effect of auditor integrity on audit quality. The coefficient for the interaction of the auditor integrity variable and emotional intelligence of 0.308 is positive, which means that the emotional intelligence variable strengthens the effect of auditor integrity on audit quality.

Table 3.4 Moderation Regression Analysis Results2 (X3.Z3)

\begin{tabular}{|c|c|c|c|c|c|c|}
\hline \multirow{2}{*}{\multicolumn{2}{|c|}{ Model }} & \multicolumn{2}{|c|}{ Unstandardized Coefficients } & \multirow{2}{*}{$\frac{\text { Standardized Coefficients }}{\text { Beta }}$} & \multirow[b]{2}{*}{$\mathrm{t}$} & \multirow[b]{2}{*}{ Sig. } \\
\hline & & $\mathrm{B}$ & Std. Error & & & \\
\hline \multirow[t]{3}{*}{1} & (Constant) & 16.379 & 6.620 & & 2.474 & .018 \\
\hline & $\mathrm{X} 3$ & .727 & .184 & .514 & 3.945 & $<.001$ \\
\hline & Moderasi3 & .408 & .151 & .352 & 2.700 & .010 \\
\hline
\end{tabular}

Based on the results of the moderating regression test of the auditor's competence variable (X3) on audit quality (Y) after interacting with the emotional intelligence variable (Z), the mathematical equation can be arranged as follows.

$$
\mathrm{Y}=16,379+0.408 \mathrm{X} 33 . \mathrm{Z3}
$$

From table 5.6.1.3, the results of the Moderation Regression Analysis show that the auditor's competence variable interacting with emotional intelligence (moderation) has a value of 0.010 below the standard value of 0.05 significance. This shows that emotional intelligence moderates the effect of auditor competence on audit quality. The coefficient for the interaction of the independence and experience variables of 0.408 is positive, which means that the emotional intelligence variable strengthens the effect of auditor competence on audit quality.

\section{DISCUSSION}

1. Auditor work experience has a positive effect on audit quality.

The results of hypothesis testing indicate that the proposed hypothesis 1 is accepted. Thus, the hypothesis which states that the work experience of auditors has a positive and significant effect on audit quality can be empirically proven on auditors who work at the Financial and Development Supervisory Agency for South Sulawesi Province. This means that the more audit experience an auditor has, the more audit quality will be followed. Conversely, if an auditor is less experienced in conducting audits, the smaller the level of audit quality produced.

The results of this study support the attitude and behavior theory which explains that the auditor will act based on the knowledge he gets. Such skills, competence, professionalism and experience in work are needed in carrying out their duties and responsibilities as an independent and qualified auditor. This attitude and behavior theory helps explain how the attitude of an auditor who is experienced in his field when conducting an audit can affect the performance of the auditor. This is consistent with the opinion of Masrizal (2010) that the work experience of auditors affects audit quality. The higher the level of a person's work experience, the better the work results will be. This can be used as a recommendation that the longer the tenure of an auditor, the more it affects audit quality.

\section{Auditor integrity has a positive effect on audit quality.}

The results of hypothesis testing indicate that the proposed hypothesis 2 is accepted. Thus the hypothesis which states that auditor integrity has a positive and significant effect on audit quality can be empirically proven on auditors who work at the Financial and Development Supervisory Agency for South Sulawesi Province. This means, an auditor who maintains his integrity will act honestly and decisively in considering the facts, regardless of personal interests. In this case, the auditor is required to act honestly and decisively in disclosing all audit evidence that is in accordance with the actual situation without being influenced by parties that can disturb the auditor's personal integrity. So that the quality of the auditor's work can be trusted by the public in accordance with the highest value order for members of the profession, because basically integrity is one of the guarantees of quality in assessing the work of auditors. 
International Journal of Social Science (IJSS)

Vol.1 Issue.5 February 2022, pp: 799-808

ISSN: 2798-3463 (Printed) | 2798-4079 (Online)

DOI: https://doi.org/10.53625/ijss.v1i5.1325

The results of this study support the attitude and behavior theory which assumes that a person's performance and behavior can be influenced by his personal abilities that come from internal strengths. Auditor integrity is part of the ability in an auditor that can affect audit quality. This is consistent with the opinion of Triandis (1971) which states that a person's behavior is determined by attitudes related to what people want to do and consists of beliefs about the consequences of doing behavior, social rules related to what they usually do. Behavior is unlikely to occur if the situation does not allow it. Auditor competence has a negative effect on audit quality.

3. Auditor competence has a negative effect on audit quality.

The results of hypothesis testing indicate that the proposed hypothesis 3 is rejected. Thus the hypothesis which states that auditor competence has a positive effect on audit quality is not appropriate for auditors who work at the Office of the Financial and Development Supervisory Agency Representative for South Sulawesi Province. This means that in carrying out audit tasks, there are 4 people assigned, namely 1 executive auditor (Senior) and 3 young auditors (Junior), this implementing auditor already has adequate competence, while these 3 young auditors have different educational backgrounds, there are from law, engineering and accounting. Before carrying out his duties an auditor must be taken with training and learning so that he is proficient and expert in the field of auditing. However, at the BPKP Representative Office of South Sulawesi Province, the competence of the auditors does not affect the success or failure of the auditors in producing quality audits because it is not enough for each auditor to only have adequate competence, but must be supported by experience and high integrity.

The results of this study contradict the attitude and behavior theory that the expertise of auditors who have knowledge, skills, competence, and professionalism affect the performance of auditors in producing quality audits. This is in line with Roland Mailuhu's (2014) research which found that auditor competence had no significant effect on audit quality. This means that although the auditors have adequate competence in carrying out audits, they are not able to improve the audit quality of the BPKP auditors in South Sulawesi Province. In contrast to the research conducted by Saputra (2012), Christiawan (2002) and Alim et al. (2007) stated that the higher the competence of the auditor, the better the quality of the examination results. but on the other hand, the lower the competence of the auditor, the lower the quality of the examination results.

4. Emotional intelligence strengthens in moderating the effect of the auditor's work experience on audit quality.

The results of the study indicate that emotional intelligence can strengthen the effect of auditors' works experience on the audit quality of auditors who work at the office of the Financial and Development Supervisory Agency for South Sulawesi Province. The results of this study support the attitude and behavior theory used to explain that emotional intelligence is a condition that describes a mood that can be controlled by one in making decisions. A BPKP auditor who has a high level of emotional intelligence will be able to control himself when carrying out his duties and responsibilities such as in conducting audits, reviews, evaluations, monitoring, and other supervisory activities on planning, implementation, and accountability for state/regional revenue accountability and financial expenditure accountability. state/regional and state/regional financial expenditure accountability.

The findings of this study are consistent with the opinion of Gebyhasnanto (2019), entitled the effect of auditor work experience on auditor ethical decision making with emotional intelligence as a moderating variable (Empirical Study of Several South Jakarta Public Accountants). The results show that work experience moderated by emotional intelligence has a significant effect on auditor ethical decision making.

5. Emotional intelligence strengthens in moderating the effect of auditor integrity on audit quality.

The findings of this study indicate that emotional intelligence can strengthen the influence of auditor integrity on the audit quality of auditors working at the Financial and Development Supervisory Agency for South Sulawesi Province.

The results of this study support the attitude and behavior theory which emphasizes the importance of an auditor's attitude of integrity to maintain and gain public trust that the audited financial statements are free from material misstatement and are able to manifest what is believed to be true into reality. Darini (2005) explains that the auditor must be trustworthy, in the sense that the auditor must provide audit quality that is trustworthy, reliable and transparent according to the auditor's standards and code of ethics.

Several previous studies such as Carolita, Rahardjo and Purba (2012) stated that integrity has a positive effect on audit quality, so the higher the integrity of an auditor, the better the audit quality he performs. This means that the relationship between integrity is in line with the implementation of audit quality.

6. Emotional intelligence strengthens in moderating the effect of auditor competence on audit quality.

The findings of this study indicate that emotional intelligence can strengthen the effect of auditor competence on audit quality, although auditor competence has no significant effect on audit quality of auditors working at the Office of the Financial and Development Supervisory Agency for South Sulawesi Province. 
The results of this study support the attitude and behavior theory which emphasizes the importance of emotional intelligence as a factor of self-awareness and self-regulation that affects audit quality in making decisions and carrying out auditor duties. Each assignment of the auditor acts as an independent party who is given the responsibility to find and resolve problems that occur in the company being audited. Emotional intelligence also talks about motivation, competence of thought maturity, personal formation with character that has integrity.

\section{CONCLUSION}

Based on the results of the analysis, it can be concluded that the variables that have a direct influence on audit quality at the Office of the Financial and Development Supervisory Agency (BPKP) Representative of South Sulawesi Province are: Auditor work experience and auditor integrity. Meanwhile, the auditor's competence has no significant effect on audit quality. Auditor's work experience with $\mathrm{p}$ value $0.032>0.05$ means that the higher the auditor's work experience (X1), the better the audit quality $(\mathrm{Y})$ produced. Auditor integrity with $\mathrm{p}$ value $0.001<0.05$ means that the higher the auditor integrity (X2), the higher the audit quality (Y). auditor competence with p value $0.746<0.05$, meaning that auditor competence (X3) has no significant effect on audit quality (Y). The results of the moderating regression analysis for the effect of emotional intelligence $(\mathrm{Z})$ in moderating the relationship between auditor's work experience $(\mathrm{X} 1)$ on audit quality $(\mathrm{Y})$ showed a probability value of $0.016<0.050$. This value indicates that emotional intelligence has a positive and significant effect in moderating the relationship between auditor work experience and audit quality. The results of the regression analysis of the influence of emotional intelligence ( $\mathrm{Z}$ ) in moderating the relationship between auditor integrity (X2) and audit quality (Y) showed a probability value of $0.010<0.050$. This value indicates that emotional intelligence has a positive and significant effect in moderating the relationship between auditor integrity and audit quality. The results of the regression analysis of the influence of emotional intelligence $(Z)$ in moderating the relationship of auditor competence (X3) to audit quality showed a probability value of $0.010<0.050$. This value indicates that emotional intelligence has a significant effect in moderating the relationship between auditor competence and audit quality.

This research was conducted inseparable from the existence of several limitations contained in the quality of the research data. These limitations include:

1. It is possible that there are several other variables that have not been included in this study that affect audit quality, such as objectivity accountability, audit tenure, and professional skepticism.

2. The results of this study are an analysis with the object of study limited to the government's internal auditors who work at the Financial and Development Supervisory Agency of South Sulawesi Province, thus allowing different results if research on the same topic is carried out on different objects and professions.

\section{SUGESSTIONS}

Based on the conclusions of the study, several suggestions are recommended to the next researchers related to the audit quality of the government's internal auditors (Financial and Development Supervisory Agency), namely:

1. Add or consider other variables that can be used to review the factors that affect audit quality.

2. For further researchers to expand the object of research by developing research samples not only to respondents who work as auditors for BPKP Representatives of South Sulawesi Province but to increase the number of sample respondents in other Provincial BPKP offices, thus allowing differences in the results of this study.

3. This study uses an instrument based on a questionnaire distributed to respondents, so that further research can use other research instruments.

4. For further research, you can also try to do this research with different research methods, for example qualitative research methods or mixed methods between qualitative and quantitative.

\section{REFERENCE}

[1] Agoes, Sukrisnoand I CenikArdana. 2009. Business and Professional Ethics. Jakarta: SalembaEmpat

[2] Alvin A, Arens, et al. 2006. Auditing and Verification Services. Edition 9. Jakarta: PT Index.

[3] Alvin A, Arens. et al. 2008. Auditing and Assurance Services, Integrated Approach. Edition 12. Jakarta: Erlangga.

[4] Alvin A, Arens. et al. 2011. Audit and Assurance Services, Book 1 (Translated by Amir Abdul Jusuf), Jakarta: SalembaEmpat.

[5] Alvin A, Arens. et al. 2012. Auditing and Assurance Services. Volume 1. Twelfth Edition. Jakarta: SalembaEmpat.

[6] Asih. 2006. Effect of Experience on Increasing Auditor Expertise in Auditing. Essay. Yogyakarta: Accounting Study Program, Faculty of Economics, Islamic University of Indonesia. 
International Journal of Social Science (IJSS)

Vol.1 Issue.5 February 2022, pp: 799-808

ISSN: 2798-3463 (Printed) | 2798-4079 (Online)

DOI: https://doi.org/10.53625/ijss.v1i5.1325

[7] Asri Usman, et al, 2014. Effect of Competence Factor, Independence and Attitude against Professional Auditor Audit Quality Improve Performance in Inspectorate (Inspectorate Empirical Study in South Sulawesi Province), IOSR Journal of Business and Management, (Online), Vol. 16, Issue 1. (www.iosrjournals.org, accessed January 2014)

[8] Anton, FX. 2010. Towards Stewardship Management Theory, Informatics Scientific Magazine, Vol.1, Faculty of Economics, AKI University Semarang.

[9] Supreme Audit Agency of the Republic of Indonesia, 2007. BPK-RI Regulation No.1 concerning State Financial Audit Standards (SKPN).

[10] Bawono, I.R. and Elisha, MulianiSinggih. 2010. Factors in Self-Auditors and Audit Quality: A Study on the 'Big Four' KAPs in Indonesia. Indonesian Journal of Accounting and Auditing (JAAI),(Online). Vol.4 No.12.

[11] Candradewi, A. A. S. P. M. 2007. Effect of Education Level, Position Hierarchy, and Work Experience on the Professionalism of Public Accounting Firm Auditors in Bali. Journal of Accounting, (Online). Vol.1 No. 1, Pg: $1-20$.

[12] Carolita, Metha Kartika. 2012. The Effect of Work Experience, Independence, Objectivity, Integrity, and Organizational Commitment to the Quality of Audit Results. Diponegoro Journal of Accounting. (On line). Vol. 1 No.1.

[13] Christiawan, Yulius Yogi. 2002. "Competence and Independence of Public Accountants: Reflection on Empirical Research Results." Journal of Accounting and Finance 4: 79-92.

[14] The image of the goddess, ajeng. 2016, Effect of Work Experience, Competence, and Independence on Audit Quality With Auditor Ethics as Moderating Variable. Essay. Yogyakarta: Accounting Study Program, Department of Accounting Education, Faculty of Economics, Yogyakarta State University

[15] Darayasa, I., and Wisadha, I. 2016. Auditor Ethics as Moderating the Effect of Competence and Independence on Audit Quality in Denpasar City. E-Journal of Accounting, 15(1), 142-170.

[16] De Angelo, L.E. 1981. Auditor Size and Audit Quality. Journal of Accounting and Economics, 3 : 183-199.

[17]Dewi, Ajeng, A. 2016. The Influence of Work Experience, Competence, and Independence on Audit Quality With Auditor Ethics as Moderating Variable (Empirical Study on Internal Auditors of the Inspectorate of the Special Region of Yogyakarta). Essay. Yogyakarta: Accounting Study Program, Department of Accounting Education, Faculty of Economics, Yogyakarta State University.

[18] Donaldson, L., \& Davis, J. H. 1991. Stewardship theory or agency theory: CEO governance and shareholder returns. (Online), Australian Journal of Management, 16:49-64.

[19]Efendy, M. T. 2010. Effect of Competence, Independence, and Motivation on Audit Quality of Inspectorate Apparatus in Regional Financial Supervision (Empirical Study on Gorontalo City Government). Thesis. Semarang: Master of Science in Accounting. Diponegoro University.

[20]Risandy, Eka., et al. 2019. Influence of Competence, Work Experience, Independence, Integrity, Professionalism, and Accountability of Auditors on Audit Quality with Auditor Ethics as Moderating Variable (Study at Inspectorate 5 Districts/Cities of Riau Province). Journal of Economics. (On line). E-Vol. 27-No.42019-pp.353-369

[21] Falihahaddaraini, et al, 2018. Analysis Of Independence, Professionalism, And Competency Effect On Internal Audit Quality With Auditor Ethics As Variable Model. Journal of Actual Accounting, (Online). Vol.5, No. 3, p.: 223-233

[22] Fitriani, Indah and Yoga LuthfiHidayat. 2013. The Effect of Objectivity and Integrity of Internal Auditors on Audit Quality, Case Study at Regional Inspectorates throughout Bandung Raya. Journal of Accounting and Financial Research, (Online). Vol. 1 No.1, pp: 61-72. [23].

[23] Febriansyah, Anggi. 2014. Factors Affecting Auditor Switching (Empirical Study on Real Estate and Property Companies Listed on the IDX). Thesis, Pekanbaru: Accounting study program, Sultan Syarif Kasim State Islamic University, Riau.

[24] Gusti Agung, Rai, I. 2011. Performance Audit in the Public Sector, Concepts, Practice, Case Studies. Salemba Four: Jakarta

[25] Ghozali, Imam. 2016. Application of Multivariete Analysis With IBM SPSS 23 Program (8th Edition). VIII Printing. Semarang: Diponegoro University Publishing Agency

[26] Halim, A., Imansari, and Wulandari, R. 2015. The Effect of Competence, Independence, Experience and Auditor Ethics on Audit Quality (Empirical Study on Auditors at Public Accounting Firms in Malang). Research Journal of Accounting Students, (Online). Vol.4 No.1. 
[27] Hajering Muhammad., et al, 2019. Moderating Ethics Auditors Influence of Competence, Accountability on Audit Quality (KAP Makassar Study). Accounting journal. (Online), Vol. 23, No.3, (http://dx.doi.org/10.24912/ja.v23i3.614, accessed 03 September 2019)

[28] Please, SofyanSyafri. 2016. Critical Analysis of Financial Statements. Jakarta: PT Raja GrafindoPersada

[29] Hasnanto, Geby. 2019. The Effect of Auditor Work Experience on Auditor Ethical Decision Making With Emotional Intelligence as a Moderating Variable (Empirical Study on Several South Jakarta Headquarters). Proceedings of the Humanist National Seminar. Pamulang University Postgraduate Program. Jakarta, December 7 th.

[30] Heider, Fritz. 1958. The Psychology of Interpersonal Relations. APA PsycBooks (Online), New York: Wiley.

[31] Hera prasanti, Dian et al, 2019. Effect of Independence, Work Experience and Competence on Audit Quality with Professional Ethics as Moderating Variable (Study on KAP DKI Jakarta). Journal of Actual Accounting. (Online). Vol.6 No.1. ISSN 2087-9695.

[32] https://www.kemenkeu.go.id/publikasi/berita/ojk-dropkan-sanksi-pada-emiten-direksi-dan-komisioner-ptgaruda-indonesia/

[33] http://www.bpkp.go.id/public/upload/unit/sakd/files/PP60Tahun2008_SPIP.pdf

[34] http://www.bpkp.go.id/sulsel/konten/140/ktur-organization.bpkp

[35] http://www.bpkp.go.id/public/upload/unit/sulsel/files/Lakip/LKj_Sulsel2019.pdf

[36] Ichrom, Mochamad. 2015. The Effect of Auditor Competence, Independence, and Motivation on Audit Quality. Journal of Accounting Science \& Research. (On line). Vol. 4 No. 1.

[37] Indonesian Accounting Association, 2011. Exposure Draft Statement of Financial Accounting Standards 16 Revised 2011. Fixed Assets. Jakarta: Financial Accounting Standards Board

[38] Indonesian Institute of Accountants, 2013. Statement of Financial Standards 01: Presentation of Financial Statements (Revised 2013). Jakarta : IAI

[39] Ilmiyati, F., \&Suhardjo, Y. 2012. The Effect of Auditor Accountability and Competence on Audit Quality. Journal of Accounting and Finance, (Online), Vol.1 No.1, pp: 1-10.

[40] Indonesian Institute of Certified Public Accountants. 2011. Public Accountant Professional Standards (SPAP). Jakarta : SalembaEmpat

[41] Beautiful, Siti Nur Mawar. 2010. The Effect of Auditor Competence and Independence on Audit Quality. Essay. Semarang: Undergraduate Program, Faculty of Economics, Diponegoro University.

[42] Iriyani, Lia Dahlia. 2016. The Influence of Competence, Independence, and Professional Auditors on Audit Quality. JIAFE (Scientific Journal of Accounting, Faculty of Economics). Vol. 2 No. 1, Issue 2, p. 16-37

[43] Juliarsa, \&Septiani, P. 2014. The Influence of Independence, Professionalism, Education Level, Professional Ethics, Experience, and Auditor Job Satisfaction on the Audit Quality of Public Accounting Firms in Bali. Udayana University Accounting E-Journal, (Online). Vol.1 No.1, Pages: 1-10.

[44] Jusup, 2001. Auditing, Book 1, Yogyakarta: YKPN College of Economics.

[45] Kisnawati, Baiq. 2012. The Effect of Auditor Competence, Independence, and Ethics on Audit Quality (Empirical Study on Government Auditors at Regency and City Inspectorates in Lombok Island). Journal of Business and Entrepreneurship. (On line). Vol.8 No.3. pp: 158-168. (accessed, November 2012)

[46] Indonesian Government Internal Auditor Code of Ethics, 2014. Indonesian Government Internal Auditor Association.

[47] Kurnia, W., and Sofia. 2014. The Effect of Competence, Independence, Time Pressure, and Auditor Ethics on Audit Quality. Trisakti Accounting Journal. (On line). Vol. 1 No. 2

[48] Kulwadee, S. 2008. Relationship Quality, Professionalism, And Audit Quality: An Empirical Study Of Auditors In Thailand. International Journal of Business Research, Vol. 8 No. 4, pp. 1-12.

[49] Report on the Performance of the Financial and Development Supervisory Agency for South Sulawesi Province Representatives. Number : LKj-009/PW21/6/2020 Date : January 15, 2020

[50] Libby, R., \& Frederick, D. 1990. Experience And The Ability To Explain Audit Findings. Journal of Accounting Research, Vol. 28 No. 2, Pages: 348-367.

[51] Linting, Indriyanti, 2013. The Influence of Competence, Objectivity, Independence and Internal Performance on Audit Quality at BRI Inspectorate Makassar. Thesis. Makassar: Undergraduate Program in Accounting, Faculty of Economics and Business. Hasanuddin University. 